\section{PENGRUSAKAN TEMPAT BERSEJARAH DALAM PERANG ANTARNEGARA SEBAGAI PELANGGARAN HUKUM HUMANITER INTERNASIONAL ${ }^{1}$}

(The Destruction of Historical Object in the War between States as the Violation of International Humanitarian Law) Oleh : Dyan F. D. Sitanggang ${ }^{2}$

Abstract. Cultural property, in this present case: historical object, is protected and respected as world's asset with great value in international law especially international humanitarian law through its various institutions and instruments. The historical object with great importance to humanity has to be protected at all times and deserves international protection. However, some people oftentimes forget its obligation and intentionally destroy such objects, even though they are well aware that States and people have the obligation to protect, respect and safeguard those objects. Hague Convention 1954 boldly states that the destruction of such objects is a violation of customs of law and international humanitarian law.

Keywords: Destruction, cultural property, historical object, armed conflict, international humanitarian law

\section{A. PENDAHULUAN}

Di dalam sejarahnya, peperangan, baik perang di dalam suatu negara ataupun perang antarnegara, namun lebih nampak dalam perang antarnegara, memang selalu menghasilkan efek kehancuran yang tidak terelakkan. Di sisi lain, beberapa pihak memanfaatkan hal tersebut-yakni kerusakan dan kehancuran yang pasti terjadi dan kerugian yang pasti didapat di masa perang-dan dengan sekenanya merusak dan menghancurkan berbagai macam objek ataupun material milik lawan

\footnotetext{
${ }^{1}$ Artikel Skripsi

${ }^{2}$ NIM 090711201
}

dengan alasan bahwa itu tidak bisa dihindari.

Di antara sekian banyak objek yang dengan sengaja diserang dan dihancurkan di dalam peperangan, peninggalan bersejarah dalam bentuk benda-benda budaya juga tempat-tempat bersejarah adalah yang paling rentan terkena dampak dari peperangan itu. Para oknum yang tidak bertanggungjawab bersembunyi dan berlindung di bawah suatu teori military necessity atau 'kepentingan militer' dan merusak serta menghancurkan benda dan tempat bersejarah yang dilindungi. Penghancuran peninggalan bersejarah secara disengaja pada saat peninggalan bersejarah tersebut tidak digunakan untuk kepentingan militer adalah suatu pelanggaran terhadap Hukum Internasional dan Hukum Humaniter Internasional yang berada di dalam lingkup Hukum Internasional, dan siapapun yang bertanggung jawab memerintahkan dan melaksanakan serangan tersebut bisa dihukum atas dasar kejahatan perang.

Dua bagian pokok permasalahan tulisan ini yakni:

1. Bagaimanakah perlindungan hukum terhadap tempat bersejarah dalam masa perang menurut Hukum Humaniter Internasional?

2. Bagaimanakah sanksi dalam Hukum Humaniter Internasional bagi pihakpihak yang menggunakan tempat bersejarah dalam masa perang serta pembatasan terhadap teori kepentingan militer?

Pengumpulan data dan bahan penulisan menggunakan Metode Kepustakaan (Library Research), yaitu suatu metode yang digunakan dengan jalan mempelajari bukubuku literatur, perundang-undangan, putusan pengadilan dan yurisprudensi, bahan-bahan lainnya dalam majalah dan surat kabar serta artikel-artikel dan jurnal yang berkaitan dengan materi pokok yang kemudian digunakan untuk mendukung 
pembahasan penulisan. Bahan-bahan yang didapat kemudian dihimpun untuk selanjutnya dianalisis secara kualitatif, dimana hasilnya disusun dalam bentuk suatu karya ilmiah.

\section{B. TINJAUAN PUSTAKA}

Para ahli telah mengemukakan berbagai definisi terhadap perang. Menurut Oppenheim, "war is contention between two or more states through their armed forces, for the purpose of over powering each other and imposing such conditions of peace as the victor pleases" (perang adalah sengketa antara dua negara atau lebih melalui kekuatan senjata mereka, dengan maksud menguasai lawan dan membangun kondisi perdamaian seperti yang diinginkan oleh pemenang). Menurut Starke, perang, dalam pengertian umum, adalah suatu pertandingan (contest) antara dua negara atau lebih, terutama dengan angkatan bersenjata mereka, dan tujuan akhir dari setiap kontestan adalah untuk mengalahkan kontestan-kontestan lain, dan membebankan syarat-syarat perdamaian. Menurut Kusumaatmadja, seperti yang dikutip oleh Haryomataram, perang adalah suatu keadaan dimana suatu negara atau lebih terlibat dalam suatu persengketaan bersenjata, disertai dengan suatu pernyataan niat salah satu pihak lain.

Istilah hukum humaniter atau lengkapnya disebut International Humanitarian Law Applicable in Armed Conflict, pada awalnya dikenal sebagai hukum perang (laws of war), yang kemudian berkembang menjadi hukum sengketa bersenjata (laws of arms conflict), dan pada akhirnya dikenal dengan istilah hukum humaniter (international humanitarian law). Istilah hukum humaniter sendiri dalam kepustakaan hukum internasional merupakan istilah yang relatif baru, lahir sekitar tahun 1970an dengan diadakannya Conference of Government Expert on the Reaffirmation and Development in Armed Conflict pada tahun 1971.

Jean Picted membagi hukum humaniter internasional dalam dua golongan besar, yaitu:

a. Hukum Perang, yang dikelompokkannya ke dalam:

1) Hukum the Hague; dan

2) Hukum Genewa

b. Hak-hak Asasi Manusia (Human Rights) Hukum humaniter internasional kemudian diberi batasan oleh Jean Picted sebagai berikut: "International humanitarian law, in the wide sense is constituted by all the international legal provisions whether written or customary, ensuring respect for the individual and his well being" (Hukum humaniter internasional, dalam pengertian luas diatur oleh semua peraturan-peraturan hukum internasional baik secara tertulis maupun kebiasaan, menjamin penghargaan kepada individu dan keberadaannya yang terlindungi dengan baik). Jean Picted juga memberikan definisi dari hukum perang (Law of War), hukum Den Haag (Law of the Hague), hukum Jenewa (Law of Geneva), dan Legislation of Human Rights. Dari batasan-batasannya itu pada pokoknya, bahwa Jean Picted menggunakan istilah hukum perang dalam dua arti yaitu hukum perang dalam arti yang sebenarnya (the law of war properly so-called) adalah hukum Den Haag, dan Picted menamakan hukum Jenewa sebagai hukum humaniter yang sebenarnya (humanitarian law properly socalled). Sedangkan yang dimaksud dengan Legislation of Human Rights adalah "legislation of human rights has as object to guarantee at all times for individuals the enjoyment of fundamental rights and liberties and to preserve them from social evils" (hukum hak asasi manusia ada sebagai jaminan bagi individu-individu untuk menikmati hak-hak fundamental dan kemerdekaan di tiap saat dan untuk melindungi mereka dari kejahatan- 
kejahatan sosial).

Kusumaatmadja, di dalam ceramahnya mengenai hukum internasional humaniter pada tanggal 26 Maret 1981, menjelaskan bahwa: “...yang dinamakan international humanitarian law itu adalah sebagian dari hukum perang yang mengatur ketentuanketentuan perlindungan korban perang berlainan dengan bagian hukum perang yang mengatur peperangan itu sendiri dan segala sesuatu yang menyangkut cara-cara melakukan perang itu seperti misalnya senjata-senjata yang dilarang."

Perlindungan hukum terhadap bendabenda budaya dalam masa konflik bersenjata diatur dalam sebuah instrumen khusus hukum humaniter internasional. Menurut Convention for the Protection of Cultural Property in the Event of Armed Conflict Den Haag tahun 1954 (Konvensi Den Haag 1954 tentang Perlindungan Benda Budaya Pada Waktu Sengketa Bersenjata), di bagian pertama pasal 1 tertulis mengenai definisi peninggalan bersejarah atau properti bersejarah yang termasuk juga di dalamnya tempat-tempat bersejarah yang dilindungi selama konflik bersenjata:

\section{Definition of Cultural Property}

For the purposes of the present Convention, the term 'cultural property' shall cover, irrespective of origin or ownership:

(a) Movable or immovable property of great importance to the cultural heritage of every people, such as monuments of architecture, art or history, whether religious or secular; archaeological sites; groups of building which, as a whole, are of historical or artistic interest; works of art; manuscripts, books and other objects of artistic, historical or archaeological interest; as well as scientific collections and important collections of books or archives or of reproductions of the property defined above; (b) Buildings whose main and effective purpose is to preserve or exhibit the movable cultural property defined in subparagraph (a) such as museums, large libraries and depositories of archives, and refuges intended to shelter, in the event of armed conflict, the movable cultural property defined in subparagraph (a);

(c) Centres containing a large amount of cultural property as defined in subparagraphs (a) and (b), to be known as 'centres containing monuments'.

Pengertian dari benda bersejarah atau peninggalan bersejarah atau benda budaya seperti yang dimaksud dalam Convention for the Protection of Cultural Property in the Event of Armed Conflict Den Haag tahun 1954 terperinci dalam tiga golongan, yaitu: (a) Barang-barang bergerak maupun tidak bergerak yang penting sekali bagi budaya setiap bangsa, seperti monumen arsitektur, tempat-tempat peninggalan bersejarah dan lain-lain; (b) Gedung-gedung yang tujuan utamanya adalah untuk memelihara atau memamerkan barang budaya yang tak ternilai seperti museum, perpustakaan, tempat menyimpan arsip, dan lain-lain; (c) Pusat-pusat yang berisikan sejumlah besar barang budaya seperti yang dimaksudkan dalam ayat (a) dan (b) di atas.

Di Indonesia sendiri telah ada hukum nasional yang mengatur mengenai perlindungan terhadap cagar budaya, termasuk di dalamnya warisan kebendaan dan tempat-tempat yang memiliki nilai penting terhadap sejarah, yakni UndangUndang Republik Indonesia Nomor 11 Tahun 2010 tentang Cagar Budaya. Dalam Pasal 1 UU ini tercantum pengertian cagar budaya dan benda cagar budaya, yakni:

1. Cagar Budaya adalah warisan budaya bersifat kebendaan berupa Benda Cagar Budaya, Bangunan Cagar Budaya, Struktur Cagar Budaya, Situs Cagar Budaya, dan Kawasan Cagar Budaya di darat dan/atau di air yang 
perlu dilestarikan keberadaannya karena memiliki nilai penting bagi sejarah, ilmu pengetahuan, pendidikan, agama, dan/atau kebudayaan melalui proses penetapan.

2. Benda Cagar Budaya adalah benda alam dan/atau benda buatan manusia, baik bergerak maupun tidak bergerak, berupa kesatuan atau kelompok, atau bagian-bagiannya, atau sisa-sisanya yang memiliki hubungan erat dengan kebudayaan dan sejarah perkembangan manusia.

3. Bangunan Cagar Budaya adalah susunan binaan yang terbuat dari benda alam atau benda buatan manusia untuk memenuhi kebutuhan ruang berdinding dan/atau tidak berdinding, dan beratap.

\section{PEMBAHASAN}

Instrumen-instrumen hukum humaniter internasional yang ada bersama-sama mengatur perlindungan terhadap tempat bersejarah dalam persiapan menghadapi konflik bersenjata, di saat konflik bersenjata dan masa pemberontakan. Di dalam hukum internasional, hukum humaniter internasional adalah bidang pertama yang memberikan perlindungan khusus terhadap tempat bersejarah. Alasan terutama dari perlindungan terhadap tempat bersejarah ini adalah tingginya nilai dan pentingnya tempat bersejarah bagi kemanusiaan.

Konvensi Den Haag tahun 1954 adalah instrumen hukum universal pertama yang menetapkan pengaturan mengenai perlindungan terhadap benda-benda budaya, dalam hal ini tempat-tempat bersejarah, dalam masa konflik bersenjata. Protokol dari Konvensi ini juga menetapkan pengaturan mengenai perlindungan khusus dalam situasi di mana wilayah suatu negara dikuasai atau diduduki oleh negara lain. Dua dekade kemudian, di dalam Protokol Tambahan dari Konvensi Jenewa 1949 ditambahkan pengaturan berkaitan dengan perlindungan terhadap benda-benda budaya, termasuk tempat-tempat bersejarah dalam masa konflik bersenjata internasional dan konflik bersenjata noninternasional; di mana kekebalan yang dimiliki oleh benda-benda warga sipil atau obyek-obyek sipil juga diberikan kepada tempat-tempat bersejarah. Di dalam Protokol-protokol ini dengan jelas mengatur bahwa pihak-pihak yang berperang dilarang untuk menjadikan tempat-tempat bersejarah sebagai sasaran militer untuk diserang dan dirusak terlebih dihancurkan, dan untuk melakukan tindakan penyanderaan terhadap tempattempat bersejarah.

Di dalam Statuta Roma yang mengatur tentang yurisdiksi Mahkamah Pidana Internasional terhadap orang-orang yang diduga telah melakukan penyerangan secara disengaja, dalam konflik/sengketa bersenjata internasional maupun noninternasional, terhadap benda-benda sipil atau "bangunan yang diperuntukkan untuk keagamaan, pendidikan, seni, ilmu pengetahuan atau tujuan-tujuan amal, monumen-monumen bersejarah yang bukan merupakan sasaran militer". Di Indonesia sendiri telah ada hukum nasional yang mengatur mengenai perlindungan terhadap cagar budaya, termasuk di dalamnya warisan kebendaan dan tempattempat yang memiliki nilai penting terhadap sejarah, yakni Undang-Undang Republik Indonesia Nomor 11 Tahun 2010 tentang Cagar Budaya.

Di dalam Konvensi Den Haag tahun 1954, prinsip umum atas perlindungan terhadap tempat bersejarah didasarkan pada obligasi untuk menjaga dan menghormati tempat bersejarah tersebut, seperti dijelaskan dalam Pasal 2 Konvensi. Penjagaan atas tempat bersejarah terdiri dari setiap langkah persiapan yang harus diambil di dalam masa damai demi tersedianya kondisi terbaik bagi 
perlindungan tempat bersejarah tersebut, seperti yang tercantum dalam Pasal 3. Sementara itu, penghormatan terhadap tempat bersejarah berarti menghindari tindakan permusuhan yang ditujukan langsung terhadap tempat bersejarah tersebut, dan melarang, mencegah dan jika perlu menghentikan segala bentuk pencurian, penjarahan atau penyalahgunaan, dan setiap tindakantindakan vandalisme yang ditujukan langsung terhadap tempat bersejarah tersebut. Hal tersebut juga berarti bahwa penggunaan tempat bersejarah untuk tujuan militer dan untuk mendukung tindakan militer adalah dilarang, seperti yang ditegaskan pada Pasal 4.

Tindakan pembalasan yang ditujukan langsung terhadap tempat-tempat bersejarah juga dilarang, dan tidak ada alasan pembenar atau pengecualian untuk tindakan pembalasan, ditegaskan dalam Pasal 4 paragraf 4 , dan terkandung dalam Pasal 53(c) dari Protokol Tambahan I 1977.

Langkah-langkah yang harus diambil untuk menjamin bahwa tempat-tempat bersejarah itu terlindungi dan dihormati yakni berkaitan dengan identifikasi dan inventarisasi, lambang, kartu identitas, pendaftaran di International Register of Property under Special Protection, penyebaran dan sanksi pidana.

a. Identifikasi dan Inventarisasi

Tempat-tempat bersejarah tersebut harus diidentifikasi dan didaftarkan. Identifikasi yakni suatu tindakan untuk menentukan dan mempertimbangkan apakah tempat bersejarah tersebut benar-benar memiliki nilai sejarah dan kebudayaan yang memerlukan perlindungan. Perlindungan ini didapatkan bersamaan dengan tanggung jawab dari elemen pemerintahan nasional. Inventarisasi yakni suatu tindakan mendaftarkan semua tempattempat bersejarah yang dilindungi dan daftar-daftar ini diserahkan pada badan- badan yang mengatur mengenai perlindungan terhadap properti bersejarah. Inventarisasi ini memuat informasi seperti berikut:

o Detail-detail umum mengenai tempat bersejarah tersebut;

- Informasi sah mengenai registrasinya di registrasi negara;

- Detail dari pemiliknya;

- Tujuan penggunaan dari tempat bersejarah tersebut (publik, pendidikan, keagamaan, dan lainlain);

- Asal usul nilai dari tempat bersejarah tersebut (arkaeologikal, historikal, artistik, dan lain-lain);

o Detail mengenai asal-muasalnya (konstruksi, tahun, periode, style, dan lain-lain);

- Pengukuran-pengukuran, bahanbahan dan teknik-teknik yang digunakan;

- Deskripsi dari tempat bersejarah tersebut;

- Detail-detail dari data grafis yang disimpan di dalam arsip tempat bersejarah tersebut: dokumendokumen, foto-foto, model, informasi audio-visual, dan lain-lain.

Sangat disarankan untuk memiliki dokumentasi simpanan untuk menjamin bahwa apabila tempat bersejarah itu rusak atau hancur, tempat bersejarah tersebut dapat dibangun kembali. Tergantung dari tipe dari tempat bersejarah tersebut, beragam cara dapat digunakan untuk mengumpulkan referensi dokumentasinya.

b. Lambang Pembeda

Tempat bersejarah bisa (di dalam kasus perlindungan umum, Pasal 6) atau harus (dalam perlindungan khusus, Pasal 10) ditandai dengan lambang. Lambang pembeda adalah sebagai berikut, menurut Pasal 16.

(1) Lambang pengenal dalam Konvensi ini berupa tameng yang mengarah 
kebawah dengan saltir biru dan putih (sebuah tameng yang terdiri dari suatu segi empat sama sisi biru yang salah satu sudutnya merupakan ujung dari tameng, dan sebuah segitiga sama sisi biru yang berada pada bagian atas; ruang disisi kiri dan kanannya terdiri dari masing-masing sebuah segitiga warna putih).

(2) Lambang harus digunakan sebuah, atau digunakan tiga buah dalam formasi segitiga (satu tameng dibawah), menurut syarat-syarat yang ditentukan dalam Pasal 17.

Tempat untuk meletakkan lambang tersebut diatur oleh masing-masing negara. Dalam kasus sengketa bersenjata tahun 1991 di Kroasia, lambang tersebut dilukis di sebuah papan dan diletakkan di tempat setinggi dua meter, di ratusan monumenmonumen dan institusi-institusi yang dilindungi.

Gambar dari lambang pembeda tersebut terlampir di Lampiran I.

Menurut Pasal 17, lambang pembeda tidak boleh digunakan di tempat bersejarah kecuali pada saat yang sama ada suatu otorisasi yang dapat diperlihatkan sepatutnya dan ditandatangani oleh penguasa yang berwenang dari negara yang bersangkutan.

Contoh peletakkan lambang terlampir di Lampiran II.

\section{c. Kartu Identitas}

Orang-orang yang bertanggung jawab untuk melindungi tempat bersejarah memegang kartu identitas khusus dengan lambang pembeda. Kartu ini mencantumkan marga dan nama awal, tanggal lahir, titel atau pangkat, dan tugas dari orang tersebut. Di kartu tersebut juga tertera foto dari pemilik, juga tanda tangan mereka atau cap jari atau keduanya. Selain itu, di kartu tersebut harus tertera cap dari otorisasi yang berwenang. Spesimen dari kartu yang digunakan harus diserahkan kepada negara-negara peserta Konvensi yang lain sebagai informasi bagi mereka. Contoh kartu identitas terlampir di Lampiran III.

d. International Register of Property under Special Protection

Tempat-tempat penampungan, pusatpusat yang memuat monumenmonumen dan benda-benda tidak bergerak lainnya yang berada di bawah perlindungan khusus (special protection) harus didaftarkan di International Register of Cultural Property under Special Protection, yang dikelola oleh Direktur-Jenderal UNESCO. Untuk mendapatkan hak perlindungan khusus, pemerintah nasional harus mengirimkan deskripsi lokasi dan segala persyaratan yang menjelaskan bahwa tempat bersejarah tersebut memenuhi kriteria untuk dilindungi secara khusus.

e. Penyebaran (Dissemination)

Agar supaya pengetahuan mengenai instrumen-instrumen hukum ini dapat tersebar, adalah hal yang sangat penting bahwa teks dari Konvensi Den Haag tahun 1954 ini beserta Aturan Pelaksanaannya untuk diterjemahkan ke dalam bahasa-bahasa nasional. Bahasabahasa resmi untuk Konvensi Den Haag tahun 1954 dan Protokol I-nya adalah Bahasa Inggris, Bahasa Perancis, Bahasa Spanyol dan Bahasa Rusia. Terjemahan resmi ke dalam bahasa lain harus dikirimkan ke Direktur Jenderal UNESCO sebagai komunikasi untuk negara-negara peserta Konvensi yang lain, seperti yang tercatat dalam Pasal 26. Protokol II dibuat dalam bahasa Inggris, bahasa Perancis, bahasa Spanyol, bahasa Mandarin dan bahasa Arab.

Obligasi-obligasi untuk perlindungan tempat bersejarah yang terdapat dalam Konvensi ini harus disebarluaskan sebisa mungkin. Untuk melakukan hal tersebut:

o Aturan-aturan internasional dan 
obligasi-obligasi nasional yang terdapat dari instrumen-instrumen ini harus dimasukkan ke dalam aturanaturan militer, dan spirit penghargaan terhadap budaya dan tempat bersejarah harus ditanamkan di antara tentara-tentara dalam masa damai (Pasal 7 dan 25);

- Pembelajaran atas aturan-aturan dan obligasi-obligasi ini harus diperluas agar supaya prinsip-prinsip yang terkandung di dalam instrumeninstrumen ini diketahui oleh seluruh populasi, khususnya orang-orang yang terlibat di dalam perlindungan tempat bersejarah (Pasal 25).

f. Sanksi pidana

Agar supaya peraturan-peraturan ini ditaati, adalah hal yang pasti untuk setiap pelanggaran mendapatkan sanksi. Penyusun sanksi pidana nasional harus menyediakan sanksi atas orang-orang yang telah melakukan pelanggaran atas Konvensi Den Haag tahun 1954 atau telah memerintahkan dibuatnya pelanggaran, tidak peduli kewarganegaraan mereka (Pasal 28).

Selama masa konflik, setiap pihak yang bersengketa harus:

- Menghindari menggunakan tempat bersejarah dan sekelilingnya yang dilindungi untuk tujuan yang memungkinkan tempat bersejarah itu untuk menghadapi kerusakan dan kehancuran, terkecuali dalam keadaan militer yang mendesak (Pasal 4, paragraf 1 dan 2);

- Menghindari segala bentuk tindakan permusuhan yang diarahkan langsung kepada tempat-temat bersejarah, terkecuali dalam keadaan militer yang mendesak (Pasal 4, paragraf 1 dan 2);

- Melarang, mencegah dan menghentikan segala bentuk pencurian, penjarahan atau penyalahgunaan dan segala tindakan vandalisme (Pasal 4, paragraf 3 );
- Menghindari tindakan mengklaim tempat bersejarah yang terletak di teritori negara lain (Pasal 4, paragraf 3);

- Menghindari segala bentuk tindakan pembalasan yang diarahkan langsung terhadap tempat bersejarah (Pasal 4, paragraf 4);

- Menghindari segala bentuk tindakan permusuhan yang diarahkan terhadap tempat bersejarah dan penggunaan tempat bersejarah yang dilindungi secara khusus untuk tujuan-tujuan militer (Pasal 9).

Selama masa okupasi atau pendudukan negara lain atas wilayah suatu negara, negara yang mengokupasi harus:

- Mendukung otorisasi nasional yang kompeten dari negara yang diduduki itu dalam hal penjagaan dan perlindungan tempat bersejarah;

- Mengambil semua langkah yang diperlukan untuk penjagaan dan perlindungan dengan kerjasama yang dekat dengan otorisasi nasional yang kompeten, apabila otorisasi nasional ini tidak dapat berbuat demikian;

- Menunjuk perwakilan khusus untuk tempat bersejarah yang terletak di daerah yang diduduki.

Harus ditekankan bahwa tanggung jawab yang terkandung di dalam segala peraturan instrumen-instrumen hukum humaniter internasional ditujukan kepada kedua belah pihak yang terlibat dalam konflik, baik pihak yang mengontrol tempat bersejarah dan pihak yang menyerang atau pihak lawan.

Teori military necessity adalah satusatunya alasan di mana kewajiban negaranegara untuk menghormati tempat bersejarah dapat diabaikan. Teori yang tercantum di dalam Konvensi Den Haag 1954 ini adalah hal yang sangat disayangkan, mengingat teori ini adalah pembenaran terhadap pelanggaran atas perlindungan tempat-tempat bersejarah. 
Meskipun demikian, penggunaan teori kepentingan militer tidak tanpa batasan. Menurut Nobuo Hayashi, sekurangkurangnya ada empat persyaratan penggunaan teori kepentingan militer: yakni 1) langkah yang diambil dengan menggunakan teori kepentingan militer harus memiliki tujuan militer yang spesifik; 2) langkah yang diambil harus benar-benar diperlukan untuk pencapaian tujuan militer; 3) tujuan militer yang dimaksud harus sesuai dengan hukum humaniter internasional; dan 4) langkah yang diambil tersebut harus sesuai dengan hukum humaniter internasional.

Langkah yang diambil yang harus benarbenar diperlukan untuk pencapaian tujuan militer yang dimaksud harus memenuhi kriteria-kriteria tertentu. Menurut Kretzmer, langkah yang diambil harus relevan dengan pencapaian tujuan militer tersebut; dari sekian banyak langkahlangkah relevan yang ada, langkah yang diambil adalah langkah yang paling tidak mengakibatkan cedera atau kerusakan; dan kerusakan yang diciptakan oleh pengambilan langkah tersebut harus sesuai dengan hasil yang didapatkan.

Menilik pada tindakan pengrusakan tempat bersejarah yang dilakukan oleh oknum-oknum yang tidak bertanggungjawab dengan bersembunyi di balik teori kepentingan militer tanpa memperhatikan batasan-batasan dan persyaratan yang diperlukan, tentu saja hal tersebut adalah suatu pelanggaran besar. Menurut ICTY Statute, pengrusakan bahkan penghancuran terhadap tempat yang dilindungi adalah pelanggaran terhadap Konvensi Jenewa 1949, pelanggaran terhadap hukum perang, dan merupakan tindakan kejahatan terhadap kemanusiaan.

Pengrusakan bahkan penghancuran tempat bersejarah dalam perang, baik international armed conflict maupun noninternational armed conflict, dapat dikategorikan sebagai kejahatan perang, seperti tercantum dalam Statuta Roma dan ICTY Statute. Sanksi terhadap pelanggaran hukum humaniter internasional diatur di dalam Konvensi Jenewa 1949 dalam ketentuan tentang 'penal sanctions'. Menurut Starke, sanksi-sanksi hukum humaniter internasional terhadap kejahatan perang antara lain pembalasan (reprisal), penghukuman baik selama maupun sesudah permusuhan berakhir terhadap penjahat-penjahat perang melalui suatu pengadilan yang layak. Menurut Lauterpacht, sarana-sarana yang dapat dipakai untuk menjamin berlangsungnya suatu legitimate warfare yakni: a) Measures of self-help, seperti reprisal, penghukuman prajurit yang melaksanakan kejahatan perang, penyanderaan; b) Protes (complaints) yang disampaikan kepada musuh, atau kepada negara netral, jasa-jasa baik, mediasi dari negara netral; c) Kompensasi.

Selanjutnya, dalam hukum humaniter internasional dikenal suatu istilah collective responsibility, yang berarti bahwa apabila terjadi pelanggaran, bukan saja pelaku pelanggaran yang harus mempertanggungjawabkan perbuatannya, akan tetapi negara juga tidak terlepas dari tanggung jawab. Ketentuan mengenai collective responsibility ini dapat ditemukan baik dalam Hague Regulations 1907 (Regulasi Den Haag 1907) maupun dalam Konvensi-konvensi Jenewa 1949 atau Protokol Tambahan 1977.

Sebagai akibat dari adanya pelanggaran tersebut, negara harus membayar ganti rugi atau kompensasi dan biasanya diatur dalam perjanjian perdamaian. Contoh perjanjian perdamaian tersebut antara lain 'The 1947 Peace Treaty with Italy', 'The 1951 Peace Treaty with Japan' dan perjanjian perdamaian Indonesia-Jepang 1958. Kendatipun demikian, meski nominal uang yang dibayarkan atas pengrusakan suatu tempat bersejarah sangat besar, tetap tidak akan bisa menyamai value atau nilai yang 
sebenarnya dari tempat bersejarah sebagai saksi dari sejarah umat manusia.

\section{PENUTUP}

\section{KESIMPULAN}

1. Disadari bahwa perlindungan bagi tempat bersejarah dalam masa perang masih kurang maksimal dan rendahnya kesadaran bahwa negara-negara memiliki obligasi di bawah hukum internasional untuk melindungi tempat bersejarah dari pengrusakan bahkan penghancuran.

2. Kendatipun telah ada pembatasan terhadap penggunaan teori kepentingan militer dalam perang, penyalahgunaan oleh pihak yang tidak bertanggung jawab tetap terjadi. Konvensi Den Haag 1954 tidak menyatakan dengan jelas sanksi hukum bagi pihak-pihak yang merusak tempat bersejarah dalam konflik bersenjata, sekalipun Protokol Tambahan I Konvensi Jenewa (1977) menyatakan bahwa penghancuran tempat bersejarah adalah pelanggaran hukum humaniter internasional. Pelaku pelanggaran hukum humaniter internasional dapat dihukum atas kejahatan perang.

\section{SARAN}

1. Tempat bersejarah harus dilindungi setiap saat, di masa damai maupun di masa perang. Pemerintah tiap-tiap negara dapat melakukan upaya identifikasi, pendataan dan pemeliharaan melalui agen khusus yang bertugas mengklasifikasikan dan menjaga tempat-tempat bersejarah. Diharapkan agar organisasi-organisasi, institusi-institusi dan lembaga-lembaga pusat dari setiap negara aktif mendukung setiap upaya pemerintah nasional dalam melindungi tempat bersejarah.

2. Diharapkan agar ada pemahaman yang cukup akan teori kepentingan militer. Tempat bersejarah harus dihindarkan dari keterlibatan di dalam perang dan tidak boleh diserang, tidak boleh dijadikan tameng pelindung, dan tidak boleh dijadikan objek balas dendam. Pelaku pengrusakan tempat bersejarah harus dikenakan sanksi yang jelas dan setimpal, dan sanksi tersebut harus dipertegas dalam sebuah aturan hukum.

\section{DAFTAR PUSTAKA}

Buku

Frits Kalshoven and Liesbeth Zegveld, Constraints on the Waging War, Geneva: ICRC, 2001

Gary D. Solis, The Law of Armed Conflict: International Humanitarian Law in War, United Kingdom: Cambridge Press, 2010

Human Rights Watch, Genocide, War Crimes and Crimes Against Humanity: $A$ Topical Digest of the Case Law of the International Criminal Tribunal for the Former Yugoslavia, United States of America: Human Rights Watch, 2006

J.G. Starke, Pengantar Hukum Internasional 2, Edisi Kesepuluh, Edisi Bahasa Indonesia terjemahan Bambang Iriana Djajaatmadja, SH, Jakarta: Sinar Grafika, 2008

Mochtar Kusumaatmadja, Hukum Internasional Humaniter Dalam Pelaksanaan dan Penerapannya di Indonesia, 1980

Prof. KGPH. Haryomataram, SH, Pengantar Hukum Humaniter, Jakarta: Raja Grafindo Persada, 2007

Syahmin A.K. SH, Hukum Internasional Humaniter, Jilid 1: Bagian Umum, Bandung: Armico, 1985

Jurnal

David Kretzmer, The Supreme Court of Israel: Judicial Review During Armed Conflict, German Yearbook of International Law, 392, 2004

Michael N. Schmitt, Military Necessity and Humanity in International Humanitarian 
Lex et Societatis, Vol. I/No.2/Apr-Jun/2013

Law: Preserving the Delicate Balance, Virginia Journal of International Law, Volume 50:4, 2010

Nobuo Hayashi, Requirements of Military Necessity in International Humanitarian Law and International Criminal Law, Boston University International Law Journal, Volume 28:39, 2010 